EVS28

KINTEX, Korea, May 3-6, 2015

\title{
Feasibility of electric buses in public transport
}

\author{
Olli Vilppo ${ }^{1}$, Joni Markkula ${ }^{1}$ \\ ${ }^{1}$ Department of Electrical Engineering, Tampere University of Technology, Korkeakoulunkatu 3 FI-33101 Tampere
} olli.vilppo@tut.fi

\begin{abstract}
This study examines the economic feasibility of electric buses in a mid-sized city, where public transport is currently organized with buses only. The difference in lifetime cost of electric buses and diesel buses was calculated with the chosen parameters that were selected after careful background analysis. A viable business case can be created when the battery and the charging infrastructure are selected shrewdly. The electricity is much cheaper fuel than diesel but with the current battery technologies and battery prices the significant cost from operating an e-bus comes from the wear of the battery. Two types of Li-ion batteries were compared, LFP (Lithium Iron Phosphate) and LTO (Lithium Titanate). Also different conductive opportunity charging strategies were examined: 1 . Charging at the depot. 2. Charging at the end stop(s). 3 . Charging at the line stops.

The round trip line length assessed was $20 \mathrm{~km}$. Calculations show that the LTO buses and a fast charger at the end stop complemented with low power overnight chargers at the depot is the best investment combination based on the given assumptions. The $200 \mathrm{~kW}$ charging power is sufficient to ensure the charging in the normal end stop breaks. Due to a longer cycle life the wear cost per km was lower for LTO than for LFP. LTO is also better adapted for fast charging. The battery size has to be sufficient compared to the required driving range during peak consumption, to the charging current and to the performance requirements of the e-bus. Oversizing the battery has some positive effects (improved cycle life, less heating and better flexibility) but the negative effects were estimated to be more significant (higher investment cost, increased weight and space requirement).
\end{abstract}

Keywords: Electric bus, LTO, LFP, Lifetime cost

\section{Introduction}

The most critical component of an electric vehicle is the battery. Battery is an energy storage device that stores electrical energy into the chemical bonds. There are different types of batteries used in the transportation but especially the development of the Li-ion batteries has furthered battery electric vehicles (BEVs) adoption. One of the major challenges with wider BEV adoption is the lack of sufficient charging infrastructure. This challenge can be tackled much easier when electrifying city buses than with passenger electric vehicles. City buses utilize the same routes, they spend the nights in the same depot and also the driving times are fixed. Locations of the chargers and utilization times can 
be optimized and bus lines can be electrified one by one.

Electric bus industry is currently in prototype phase and the industry holds lot of potential.

This article presents a case study of the current situation of the economic feasibility, when electrifying one whole city line compared to operating the line with diesel buses. Besides potential monetary savings the electric buses have environmental advantages over the diesel buses. They reduce the pollution and the noise level in the city. The e-buses can improve the city image considerably.

\section{Test set up and the cost structure}

Our case study was related to examining the feasibility of electric buses in the Tampere city public transport focusing in economic feasibility. Tampere is a city of 220000 people and currently the public transportation is organized only by buses. City's own public bus operator serves majority of the lines within the city area. Some lines are served by private bus-operators. In Tampere city the buses usually drive through slow city center and have the end stops in the different residential districts of the city. The other end stop is in some cases located in the city center. For the first city line to be electrified the one route with round trip length of $20 \mathrm{~km}$ and average speed of $20 \mathrm{~km} / \mathrm{h}$ was examined.

The financial calculations were made by comparing costs between the electric buses and diesel buses. Only the costs that are different between bus types are considered in the analysis. The costs included in the analysis are the investment cost of the buses, fuel or energy cost and the maintenance cost. For the electric buses there are also the battery replacement cost and the investment cost of the charging infrastructure and its maintenance cost.

The costs excluded from the analysis that don't differ between bus types include driver wage, depot related costs, insurances and vehicle inspection costs.

\section{Battery properties}

The batteries are in key position in the calculations. There are different types of Li-ion batteries that contain different cathode, anode and electrolyte materials. Currently two main types of battery chemistries are used in the commercial buses namely LFP (Lithium Iron Phospate) and the more recent LTO (Lithium
Titanate) and they were evaluated in the calculations. Before the financial calculations also the size of the battery has to be defined.

Performance parameters vary between different chemistries. They include power density $(\mathrm{W} / \mathrm{kg})$, energy density $(\mathrm{Wh} / \mathrm{kg})$, maximum charging and discharging rates (C-rates), lifetime (calendar life and cycle life), charging efficiency, cost and safety.

\subsection{Wear of the battery}

The battery wear cost can be allocated per $\mathrm{km}$. This is useful when different battery chemistries are compared. In the e-bus operation with the current battery technologies the cost of the battery wear is more significant than the cost of electricity. The acquiring cost per $\mathrm{kWh}$ varies between different Li-ion batteries but the final cost depends on how many kilometers can be driven with one battery in its lifetime. Besides acquiring price, the cycle life of the battery is a critical parameter in the economic calculations. The price per kilometer was calculated with the formula (1). In the formula the wearing effect of the regenerative braking is neglected. The regenerative braking consists of micro cycles, which should wear the battery considerably less than the deeper cycle charging from the grid as it is suggested in [1]. The battery is usually at the end of its life, when $80 \%$ of the original capacity remains [2]. In the formula simplification is made that the capacity fade of the battery happens linearly, hence the capacity is on average throughout the lifetime $90 \%$ of the original.

$a=\frac{p \cdot c}{0.9 \cdot y}$

$\mathrm{a}=$ Price of battery per kilometer $(€ / \mathrm{km})$

$p=$ Acquiring price of the battery $(€ / \mathrm{kWh})$

$\mathrm{y}=$ Cycle life (full cycles) (pcs)

$\mathrm{c}=$ Consumption of the e-bus $(\mathrm{kWh} / \mathrm{km})$

\subsection{Acquiring price of the battery}

The battery pack is composed of cells, thermal and electronic management and structural support. In [3] the cost of manufacturing LFP cell is estimated to be about $300 \$ / \mathrm{kWh}$ and LTO cell about 300$600 \$ / \mathrm{kWh}$. Automotive cells and especially e-bus cells are more expensive to produce than the smaller consumer cells due to tighter safety requirements and quality control challenges of manufacturing large cells. The whole battery pack cost includes also the other components. In table 1 
the pack price/ $\mathrm{kWh}$ is estimated for $\mathrm{EV}$ with 22 kWh Li-ion battery. [4]

Table 1: EV battery price formation [4]

\begin{tabular}{|c|c|}
\hline Cost structure & $\mathbf{\$ / k W h}$ \\
\hline Cells & 400 \\
\hline Other pack materials* & 238 \\
\hline $\begin{array}{c}\text { Pack overheads, } \\
\text { depreciations and labor }\end{array}$ & 54 \\
\hline Margin and warranty & 100 \\
\hline In total & 792 \\
\hline
\end{tabular}

*Other pack materials include BMS (Battery Management System) wiring harnesses, interconnections and connectors, internal cell support, forced air temperature control and housing.

The table 1 figures are estimates for passenger electric vehicles with 20000 pack annual manufacturing volume. At the current industry prototype phase electric bus batteries are very specific solutions and don't have big volumes yet. Hence the e-bus batteries prices are higher.

The current acquiring prices of the e-bus batteries used in the calculations were for LTO batteries $2000 € / \mathrm{kWh}$ and for LFP $900 € / \mathrm{kWh}$. The prices of the batteries are predicted to continue lowering in the near future [4] [5]. Based on the cell costs, it is reasonable to assume that LTO battery pack has more potential to lower its price in the future than the LFP pack.

\subsection{Cycle life}

LFP's cathode is $\mathrm{LiFePO}_{4}$ and its anode is graphite. Graphite limits the cycle life typically to maximum of 3000 (100\% DoD, depth of discharge) [6]. LTO's anode is $\mathrm{Li}_{5} \mathrm{Ti}_{7} \mathrm{O}_{12}$. With LTO-battery the announced cycle life in manufacturer's spec sheets vary with the changing cathode materials. Typically cycle life is announced between $10000-16000(100 \%$ DoD) [7] [8]. To ensure the long cycle life the charging current should remain under the C-rates provided by the battery manufacturer.

The proper working BMS is crucial in achieving the desired cycle life as it will take care of balancing the cell voltages and temperature control of the cells. To ensure the maximum cycle life the temperature of the battery should remain close to the $25^{\circ} \mathrm{C}$ during the charging and discharging. The temperature control is especially important in Finnish climate where the outside temperature varies between $+30^{\circ} \mathrm{C} \ldots-30$ ${ }^{0} \mathrm{C}$. To ensure a good operation environment the batteries should be thermally protected from the cold weather. At the same time the cooling of the battery has to work, especially during the fast charging.

\section{Consumption of the electricity}

Consumption of the e-bus means here the energy used from the battery. The grid consumption means the energy that the bus operator pays for, which includes the losses during charging. There is not much publicly available data on the consumption behavioral of the electric buses. The bus manufacturers give usually some consumption number in their website. In order this number to be reliable the driving cycle, passenger weight and the heating and air conditioning consumption in addition to the propulsion should be stated.

In general compared to a diesel bus an e-bus should create most saving in the slow routes with lot of stoppage time. This is due to the torque curve of electric motor. The electric motor doesn't need the idle and it has high torque at low speeds, which provides fast acceleration. Also the braking energy can be recuperated.

\subsection{Propulsion}

In Finnish e-bus project a 12 meter prototype electric bus "test-Mule" was constructed. [9] The consumption numbers of "Mule" measured by VTT (Technical research Center of Finland) in the laboratory with chassis dynamometer are used here as a reference consumption for e-bus. The characteristics of the cycles applied are presented in table 2. The measurement results are presented in table 3. These dynamometer results exclude the passenger department consumption of opening the doors and heating and air conditioning.

In winter in addition of the heating energy needed, the propulsion consumption can increase, because of weather conditions, by approximately $5 \%$. This estimation was derived from the higher resistance $(16 \%)$ of the cold air and from the higher rolling resistance (6-9\%) due to a snow on the street [11] and from the figures that the rolling resistance makes up $35 \%$ and air drag about $10 \%$ of the total propulsion consumption [9].

Table 2: Characteristic of driving cycles [9]

\begin{tabular}{|c|c|c|c|c|c|}
\hline $\begin{array}{c}\text { Driving } \\
\text { cycle }\end{array}$ & $\begin{array}{c}\text { Time } \\
(\mathrm{sec})\end{array}$ & $\begin{array}{c}\text { Av. } \\
\text { speed } \\
(\mathrm{km} / \mathrm{h})\end{array}$ & $\begin{array}{c}\text { Dis- } \\
\text { tance } \\
(\mathrm{km})\end{array}$ & $\begin{array}{c}\text { Idle } \\
(\%)\end{array}$ & $\begin{array}{c}\text { Stops } \\
\text { per } \\
\mathrm{km}\end{array}$ \\
\hline $\begin{array}{c}\text { Braun- } \\
\text { schweig }\end{array}$ & 1750 & 22.6 & 10.9 & 26 & 2.65 \\
\hline $\begin{array}{c}\text { Espoo } \\
\text { L11 }\end{array}$ & 1372 & 23.7 & 9.0 & 20 & 2.10 \\
\hline
\end{tabular}


Table 3: Consumption values of a test e-bus "Mule" measured in VTT with different driving cycles and with different load in chassis dynamometer [10]

\begin{tabular}{|c|c|c|c|}
\hline & $\begin{array}{c}13 \text { pass. / } \\
1000 \mathrm{~kg}\end{array}$ & $\begin{array}{c}40 \text { pass. / } \\
3000 \mathrm{~kg}\end{array}$ & $\begin{array}{c}70 \text { pass. / } \\
5500 \mathrm{~kg}\end{array}$ \\
\hline Braun- & 680 & 810 & 1000 \\
schweig & $\mathrm{Wh} / \mathrm{km}$ & $\mathrm{Wh} / \mathrm{km}$ & $\mathrm{Wh} / \mathrm{km}$ \\
\hline Espoo & 520 & 620 & 780 \\
L11 & $\mathrm{Wh} / \mathrm{km}$ & $\mathrm{Wh} / \mathrm{km}$ & $\mathrm{Wh} / \mathrm{km}$ \\
\hline
\end{tabular}

The table 3 gives an idea how the driving cycle affects the consumption. The consumption in the calculated Tampere cycle was estimated to be close to Braunschweig cycle, because similar amount of stops.

The table 3 also gives an idea how the total weight of the bus with varying passenger amount affects the propulsion consumption. Also the curb weights (total weight of a vehicle with standard equipment without passengers) vary significantly between the different bus manufacturers, depending on the chassis material and on the battery. The curb weight of Mule is just over $8000 \mathrm{~kg}$, because of lightweight aluminum chassis and prototype sized $56 \mathrm{kWh}$ LFP battery. [9]

\subsection{Passenger consumption}

department

Diesel engine has a low efficiency, and the produced heat can be used to heat the passenger department. In electric engine there is not much heat generation as the efficiency is much higher. To save the electricity that is used from the battery during the heating and air conditioning, an air source heat pump can be installed. In winter below $-15{ }^{\circ} \mathrm{C}$ the air source heat pump loses its efficiency. For the cold days an auxiliary heater can be utilized, that consumes for example biogas or heating oil. Heating solely with electricity would require large reserve from the battery. On the coldest dates the heating of the passenger area can consume twice the energy required for propulsion [11] [12]. On average day the heating of the passenger department is not a significant consumption from the battery, when compared to the propulsion consumption. The maximum energy withdrawn from the battery is still important parameter when sizing the battery. With $4 \mathrm{~kW}$ heat air source pump the maximum consumption would be ca. 0.2 $\mathrm{kWh} / \mathrm{km}$.

Door opening has a minor effect on total consumption, about $1 \mathrm{Wh}$ energy consumption every time 3 electric doors are opened and closed. Pneumatic operated doors have higher consumption, at most couple of percentages of the total bus consumption. [13]

\subsection{Total consumption}

The total consumption of the e-bus used in the calculations (9000 kg curb weight) was estimated to be on average $1 \mathrm{kWh} / \mathrm{km}$. This signifies a light aluminum chassis and a small battery. Traditionally the curb weight with steel chassis is $3000 \mathrm{~kg}$ heavier. The weight of the bus can be used to approximate the propulsion consumption increase. In [14] the approximate number of 0.08 $\mathrm{kWh}$ per $\mathrm{km}$ per ton is stated.

The consumption varies from the average and the peak consumption happens in the winter during the congestion.

\section{Fuel and energy cost}

The fuel consumption depends on the size of the vehicle. In this research 12 meter length buses were compared. Diesel bus average consumption in TKL is $401 / 100 \mathrm{~km}$ and it was used in the calculations. The e-bus consumption was estimated in the previous chapter.

Forecasting the fuel prices for the service life of the bus (12 years) is difficult. The fuel prices are dependent of the market prices, cost of delivering the fuel and country's taxation. The market price development depends greatly on supply and demand. In short term the crude oil market price has been forecasted to decline [15] but in longer term perspective diesel price can be anticipated to rise because of the exhaust gas reduction goals. In the calculations diesel price level, $1.2 € / 1$ without VAT, is applied throughout the whole operating life.

The electricity prices in Finland are anticipated to remain quite steady in the next years based on the power market future contracts. [16]. On top of the electricity price (and electricity seller's margin) there is also a distribution network grid fee. Total price of $0,079 € / \mathrm{kWh}$ without VAT is applied throughout the whole operating life.

As noted earlier the electric bus has also some auxiliary heating cost on the cold dates. The cost of this was estimated to be about $1000 € /$ year.

\section{The maintenance cost}

The maintenance costs for diesel buses are known from the historic data. The average maintenance costs of diesel buses are described in table 4 for the fleet of TKL's diesel buses. The maintenance costs 
for the electric buses have to be estimated, because there are not much empirical data found yet. The estimation was done by addressing the question: "How would the table 4 categories of maintenance costs change, when the bus has an electric motor and electric powertrain?"

Table 4: Average maintenance cost structure of diesel buses in TKL [17]

\begin{tabular}{|c|c|}
\hline $\begin{array}{c}\text { Maintenance costs of diesel } \\
\text { bus/km }\end{array}$ & cents/km \\
\hline Brakes and work related & 3.5 \\
\hline Regular upkeep & 3.5 \\
\hline Tires & 3 \\
\hline Collision repair & 2 \\
\hline Cleaning & 3 \\
\hline Fault repair & 10 \\
\hline In total & $\mathbf{2 5}$ \\
\hline
\end{tabular}

The brake costs: Due to the regenerative braking the electric bus brakes wear out slower than the diesel bus brakes.

Regular upkeep: The e-bus doesn't need the regular change of motor-oil, oil-filter, dieselfilter, oil-rotor seal, air-filter or gear-box oil. The cost of these materials is at TKL about 1 cent $/ \mathrm{km}$ + the work performed. [17]

Fault repair: Electric motors have less wearing parts than diesel-motors and the most costly faults for diesel buses are in the motors. However the electric bus technology is new and new types of faults could emerge. Also the education of mechanics for the new faults should be considered for e-buses.

Other costs: tire wear, cleaning and collision repair should be the same regardless of the bus type. In the calculations a conservative number of 22 cents $/ \mathrm{km}$ maintenance cost for e-bus was selected.

\section{Conductive charging strategies}

The term opportunity charging indicates that the normal bus stoppage time is utilized in charging the electric bus. In other words no additional stoppage time is dedicated for the charging. Acting this way the same passenger service level can be maintained after diesel bus is replaced with the electric bus. Financially this signifies that relatively high indirect costs of additional driver time and vehicle time can be avoided.

Three main types of opportunity charging strategies can be named: 1. Depot charging. 2 . End stop charging. 3. The line stop charging.
With the depot charging the bus is charged only during the night in the depot. The energy stored in the battery has to cover the daily mileage. This signifies a big battery but the positive side is that every bus needs only one charger at the depot. From the two candidates examined here, the LFPbattery with bigger energy density is chosen, because big sized LTO battery would take too much space inside the bus and would be too expensive.

With the end stop charging the battery is charged several times during the day at the end stop(s) with a fast charger. Both LTO and LFP could be potentially selected. Because LTO can be constantly charged with $6 \mathrm{C}$, it can be much smaller than LFP that can be charged with $1 \mathrm{C}$. In the short routes, less than 30 kilometers roundtrip, the end-stop waiting time of the driver can be shifted to one end of the route in order to need only one charger/route. For LTO the longer round trip routes require fast charger in both terminals if the sizes of the batteries are not increased. The cost of fast charger is divided between the e-buses that utilize it. Usually longer routes have more buses operating and the utilization and the costs are balanced. Terminals that are shared by multiple bus lines could be equipped with multiple port fast chargers to increase the savings.

With the line stop charging the battery would be in addition to the end stop charging also charged at the line stops while people are disembarking and embarking. This would enable more range for the battery. This type of line stop charging is in use in Geneva with TOSA concept, where the $400 \mathrm{~kW}$ flash feeding sub-station charges the 18 meter bus battery for 15 seconds time [18]. This strategy is however very costly and doesn't suit to a smaller city like Tampere for two reasons. The time spend in the bus stop is short and the charging doesn't create enough economic value to justify the expensive charger in the bus line with few buses. In case there were already many electric bus lines using the same stop the cost of the charger could be divided to much more buses making the investment more reasonable. However, this would create another problem of potentially overlapping schedules where different buses come to the stop at the same time. 


\section{Sizing of the battery}

\subsection{Lower limit for the size of the battery}

There are three important factors to consider when setting the lower size limit for the battery. The First minimum battery size constraint comes from the technical requirements of the bus. The power gotten out of the battery has to be sufficient for the maximum operational speed and for the uphill acceleration of the bus. This is defined with output power (power density and discharging C-level). The second minimum constrain comes from the charging current. The battery size has to be sufficient in comparison to the charging current. This is especially important to consider with the fast charging and with the regenerative breaking. These C-rates of charging should remain in the levels that won't age the battery prematurely. Different battery chemistries have different safe C-rates. The third minimum constrain for the size of the battery is the desired driving range of the bus with one full charge. This should be scaled with the peak consumption (in winter and maximum amount of passengers).

\subsection{Upper limit for the size of the battery}

Increasing the battery size from the minimum size has negative and positive effects. This is a typical trade off situation, where the effects should be evaluated against each other. The considered effects are listed here and no exact numbers are presented in this paper.

\subsubsection{Negative effects with oversizing}

By oversizing the weight of the battery goes up and so does the consumption of the bus. Also the maximum passenger capacity decreases, when the size of the battery increases inside the bus. The extra capital invested into the battery has a negative financial effect. The effect is highlighted, because the prices of the batteries are predicted to go down also in the near future [4] [5].

\subsubsection{Positive effects with oversizing}

By oversizing the battery the relative cycle life can be extended, when the SOC (state of charge) increase is smaller in charging (and DoD in discharging) [1] [19] [20]. The behavioral is similar to all the Li-ion chemistries but some are affected more than the others. [4]
Also high voltage stresses the battery and this can be avoided by not charging the battery full. With fast charging the battery reaches the maximum allowed voltage quicker. Before maximum voltage is achieved LTO can be filled to $94 \%$ capacity, when charged with $6 \mathrm{C}$. If the cell is charged to $100 \%$ capacity a current taper should be applied which would slow down the fast charging process. [21]

Leaving extra capacity in the lower end of the battery allows some flexibility in charging at the end stops, when the bus is late and will have more time to charge next time it returns to the end stop, but is currently delayed from the schedule.

For a particular chemistry the resistance of the battery is inversely proportional to its Ah-size. The smaller battery heats up more, which requires more cooling energy for the battery. This is especially important during the fast charging. Also when the battery is bigger it has more surface area to cool down.

\section{The parameters in the example calculations}

The parameters that were used in the cash flow calculation in Excel are presented in the tables 5, $6,7,8$ and 9 . The examined $20 \mathrm{~km}$ round trip route is operated by 4 buses that drive approximately $200 \mathrm{~km}$ per day. The maximum mileage for the bus that has the longest shift is about $265 \mathrm{~km}$ per day. The mileage in a year is approximately $70000 \mathrm{~km}$ per bus as the bus can be anticipated to have some maintenance days also. $200 \mathrm{~kW}$ fast charger at the one end of the line is sufficient to deliver enough energy in 6 minutes. In the morning and afternoon traffic the bus is typically 5 minutes late but also during these times the normal end stop time is sufficient for charging.

Table 5: The battery related parameters and costs

\begin{tabular}{|c|c|c|}
\hline Bus type & LFP & LTO \\
\hline Battery Initial cost & $\begin{array}{c}900 \\
€ / \mathrm{kWh}\end{array}$ & $\begin{array}{c}2000 \\
€ / \mathrm{kWh}\end{array}$ \\
\hline $\begin{array}{l}\text { Estimated battery } \\
\text { cost when changed }\end{array}$ & $\begin{array}{c}700 \\
€ / \mathrm{kWh}\end{array}$ & $\begin{array}{l}1300 \\
€ / \mathrm{kWh}\end{array}$ \\
\hline $\begin{array}{c}\text { Battery cycle life } \\
(100 \% \text { DoD })\end{array}$ & 3000 & 12000 \\
\hline $\begin{array}{l}\text { Battery energy } \\
\text { densities }\end{array}$ & $130 \mathrm{Wh} / \mathrm{kg}$ & $65 \mathrm{Wh} / \mathrm{kg}$ \\
\hline
\end{tabular}




\subsection{Sizing LFP with depot charging}

Utilizing solely overnight charging the physical size of the LFP battery becomes problematic. The sizing should consider the day that the bus has its highest consumption (in winter), the capacity fade of the battery over lifetime and the bus weight increase. Considering all of these would translate to at least $400 \mathrm{kWh}$ battery and the battery physical size would eliminate part of the passenger capacity making the comparison unequal to the diesel option. Even though the maximum mileage would be shorter and thus feasible with only depot charging the high wear cost of LFP battery $0.38 € / \mathrm{km}$ (100\% DoD) would make the economics unattractive.

\subsection{Sizing LTO and LFP with end stop charging}

In LTO battery sizing $6 \mathrm{C}$ charging rate, $200 \mathrm{~kW}$ charging power and the faded battery capacity at the end of life are taken into account. These translate to $42 \mathrm{kWh}$ LTO battery.

The negative effects with oversizing LTO were currently estimated to be more meaningful than the positive aspects. This is mainly because of the estimated battery price reduction. LTObattery gets some of the oversizing benefits in terms of the $20 \mathrm{~km}$ required range. During charging the SOC increase is $50 \%-60 \%$. With these swings, there is margin to not charge the battery full. This has positive effect on cycle life. In the battery life time estimate the energy derived from 12000 full cycles was used in the calculations.

The end stop charged LFP is sized with $1 \mathrm{C}$ charging rate to $200 \mathrm{kWh}$. The capacity will fade over lifetime but also the $160 \mathrm{~kW}$ is enough charging power due to a large battery reserve. All of the consumption doesn't have to be charged back when the bus is late and other times it has extra time to charge. The LFP SOC increase in charging is in the range of $10-15 \%$.

The life time estimation with this short DoD is difficult. With the energy derived from 3000 full cycles the battery would last about 7 years. However it is reasonable to assume that a LFP battery that has a life of $\mathrm{X}$ with $100 \% \mathrm{DoD}$ cycles would provide more than $7 \mathrm{X}$ number of cycles of $15 \% \mathrm{DoD}$. If the number is increased to more than $12 \mathrm{X}$ costly battery change would not be needed. This type of behavior is suggested in [20] for LFP.

Table 6: The e-bus related parameters

\begin{tabular}{|c|c|c|}
\hline Bus type & $\begin{array}{c}\text { LTO 42 } \\
\text { kWh }\end{array}$ & $\begin{array}{c}\text { LFP 200 } \\
\text { kWh }\end{array}$ \\
\hline Price of the bus & $384000 €^{*}$ & $480000 €^{*}$ \\
\hline $\begin{array}{c}\text { Grid electricity } \\
\text { consumption }\end{array}$ & $\begin{array}{c}1.1 \\
\mathrm{kWh} / \mathrm{km}\end{array}$ & $\begin{array}{c}1.18 \\
\mathrm{kWh} / \mathrm{km}\end{array}$ \\
\hline $\begin{array}{c}\text { Vehicle } \\
\text { consumption }\end{array}$ & $\begin{array}{c}1.0 \\
\mathrm{kWh} / \mathrm{km}\end{array}$ & $\begin{array}{c}1.07 \\
\mathrm{kWh} / \mathrm{km}\end{array}$ \\
\hline $\begin{array}{c}\text { The maintenance } \\
\text { cost }\end{array}$ & \multicolumn{2}{|c|}{$0.22 € / \mathrm{km}$} \\
\hline $\begin{array}{c}\text { The auxiliary } \\
\text { diesel heater cost }\end{array}$ & \multicolumn{2}{|c|}{$1000 € / \mathrm{year}$} \\
\hline
\end{tabular}

*Includes the first battery and pantograph and contact dome on the bus $20000 €$.

Table 7: The diesel bus parameters

\begin{tabular}{|c|c|}
\hline Bus type & Diesel \\
\hline Price of the bus & $250000 €$ \\
\hline Vehicle consumption & $0.41 / \mathrm{km}$ \\
\hline The maintenance cost & $0.25 € / \mathrm{km}$ \\
\hline
\end{tabular}

Table 8: The average fuel costs next 12 years

\begin{tabular}{|c|c|}
\hline Grid fee (VAT 0 \%) & $0.041 € / \mathrm{kWh}$ \\
\hline Electricity price (VAT 0 \%) & $0.038 € / \mathrm{kWh}$ \\
\hline Diesel price (VAT 0 \%) & $1.2 € / 1$ \\
\hline
\end{tabular}

Table 9: Charging infrastructure costs

\begin{tabular}{|c|c|}
\hline Depot charger per bus & $5000 €$ \\
\hline $\begin{array}{c}\text { One automatic } 200 \mathrm{~kW} \text { fast } \\
\text { charger }\end{array}$ & $200000 €$ \\
\hline $\begin{array}{c}\text { Maintenance of depot } \\
\text { charger }\end{array}$ & $250 € /$ pc/year \\
\hline $\begin{array}{c}\text { Maintenance of the fast } \\
\text { charger }\end{array}$ & $3000 € /$ year \\
\hline
\end{tabular}

\section{Results of the example calculation}

The cash flow analysis of the costs was performed for the end stop charged LTO bus line (table 10), end stop charged LFP bus line (table 11) and for diesel bus line (table 12) with the discount rate of 3 $\%$. First year costs include the investment cost of buses and the charging infrastructure cost for the electric buses. The maintenance and fuel or energy cost take place every year. The LTO bus battery change takes place after 6.5 years.

By comparing the NPVs (Net Present Value) it can be seen that the LTO bus line (NPV of costs 2.9 $\mathrm{M} €)$ saves money in 12 year period compared to the diesel bus line (NPV of costs $3.1 \mathrm{M} €$ ). The cost of LFP bus line (NPV of costs $3.1 \mathrm{M} €$ ) is at the level of the diesel buses' but only if battery replacement is not needed because of low DoD. 
Table 10: Cash flow of the costs with end stop charging and operating with 4 buses with $42 \mathrm{kWh}$ LTO battery (numbers in $1000 €$ )

\begin{tabular}{|c|c|c|c|c|c|c|c|c|c|c|c|c|}
\hline Year & $\mathbf{2 0 1 5}$ & $\mathbf{2 0 1 6}$ & $\mathbf{2 0 1 7}$ & $\mathbf{2 0 1 8}$ & $\mathbf{2 0 1 9}$ & $\mathbf{2 0 2 0}$ & $\mathbf{2 0 2 1}$ & $\mathbf{2 0 2 2}$ & $\mathbf{2 0 2 3}$ & $\mathbf{2 0 2 4}$ & $\mathbf{2 0 2 5}$ & $\mathbf{2 0 2 6}$ \\
\hline Buses & 1629 & 91 & 91 & 91 & 91 & 91 & 309 & 91 & 91 & 91 & 91 & 91 \\
\hline Infra & 224 & 4 & 4 & 4 & 4 & 4 & 4 & 4 & 4 & 4 & 4 & 4 \\
\hline NPV & 2911 & \multicolumn{1}{|l}{} \\
\hline
\end{tabular}

Table 11: Cash flow of the costs of end stop charging and operating with 4 buses with $200 \mathrm{kWh}$ LFP battery in case battery change is not needed, because of low DoD (numbers in $1000 €$ )

\begin{tabular}{|c|c|c|c|c|c|c|c|c|c|c|c|c|}
\hline Year & $\mathbf{2 0 1 5}$ & $\mathbf{2 0 1 6}$ & $\mathbf{2 0 1 7}$ & $\mathbf{2 0 1 8}$ & $\mathbf{2 0 1 9}$ & $\mathbf{2 0 2 0}$ & $\mathbf{2 0 2 1}$ & $\mathbf{2 0 2 2}$ & $\mathbf{2 0 2 3}$ & $\mathbf{2 0 2 4}$ & $\mathbf{2 0 2 5}$ & $\mathbf{2 0 2 6}$ \\
\hline Buses & 2011 & 92 & 92 & 92 & 92 & 92 & 92 & 92 & 92 & 92 & 92 & 92 \\
\hline Infra & 224 & 4 & 4 & 4 & 4 & 4 & 4 & 4 & 4 & 4 & 4 & 4 \\
\hline NPV & 3121 & \multicolumn{1}{|l}{} \\
\cline { 1 - 7 }
\end{tabular}

Table 12: Cash flow of the costs of operating the line with 4 diesel buses (numbers in $1000 €$ )

\begin{tabular}{|c|c|c|c|c|c|c|c|c|c|c|c|c|}
\hline Year & $\mathbf{2 0 1 5}$ & $\mathbf{2 0 1 6}$ & $\mathbf{2 0 1 7}$ & $\mathbf{2 0 1 8}$ & $\mathbf{2 0 1 9}$ & $\mathbf{2 0 2 0}$ & $\mathbf{2 0 2 1}$ & $\mathbf{2 0 2 2}$ & $\mathbf{2 0 2 3}$ & $\mathbf{2 0 2 4}$ & $\mathbf{2 0 2 5}$ & $\mathbf{2 0 2 6}$ \\
\hline Buses & 1204 & 204 & 204 & 204 & 204 & 204 & 204 & 204 & 204 & 204 & 204 & 204 \\
\hline NPV & 3095 & \multicolumn{10}{|l|}{} \\
\hline
\end{tabular}

\section{Discussion}

The battery is the critical component in the calculations. To reduce the buyers risk guarantees about the lifetime from the manufacturer can be required. The guarantee offering battery or vehicle manufacturer should be a trusted and financially strong party.

Prices of the charging stations were rough estimations. Prices vary greatly and should be checked from the manufacturer. It is recommended to prefer the open protocol systems to avoid the lock in to one manufacturer.

Cost for building and strengthening the electric grid are highly dependent of the present conditions of the city grid. Different government incentives might be available to lower the charging infrastructure cost for the city. The diesel price level affects the calculations considerably and since the calculations were initially done in the summer of 2014 the diesel market price has declined with the crude oil market price. Still the average price of $1.2 € / 1$ (VAT $0 \%$ ) seems like a reasonable estimate for the next 12 year period.

In the calculations the end stop fast charging was assumed to work $100 \%$ of the time. Inoperative fast charging is a large cost driver as the small battery buses can't be operated that time. In case the charging fails it is important that the bus has enough energy left to drive back to depot. That way at least the towing expenses can be avoided.

\section{Conclusion}

The LTO buses and a fast charger at the end stop complemented with low power overnight chargers at the depot is the best investment combination based on the given assumptions. The end stop charging offers the best way to reduce the battery size with the reasonable infrastructure cost. The reason backing the LTO selection is the lowest battery wear cost per $\mathrm{km}$. This is because of a superior cycle life.

The low energy consumption of an e-bus is important as it affects not only the energy cost but the battery wear cost and the time required for charging.

Electric bus industry is currently in the prototype phase and the buses and batteries are likely to improve and their prices to lower in the future. Also the same phenomena can be expected from fast chargers. Already the present technology is capable to create savings, when compared to traditional diesel buses, when the total cost of ownership is calculated. To be successful e-bus project requires careful planning and interplay of different parties (city, operator, grid owner and manufacturers). Electric bus adoption is encouraged by the authors.

\section{References}

[1] Chawla M., Rajendra N., Rajni B., Wiegman H., Utility Energy Storage Life Degradation Estimation Method. GE Global Research. Innovative Technologies for an Efficient and Reliable Electricity Supply (CITRES), 2010 IEEE Conference, Page 302-308, ISBN 978-1-42446076-2. 
[2] Goodenough, J. B., Park, K., The Li-Ion Rechargeable Battery: A Perspective. Journal of the American Chemical Society, 135 (2013) 1167-1176. DOI $=10.1021 / \mathrm{ja} 3091438$.

[3] Choi D., Wang W., Viswanathan V., Yang G., Low Cost, Long Cycle Life, Li-ion Batteries for Stationary Applications. Pacific Northwest National Laboratory [WWW] Retrieved 13.10.2014 from http://www.sandia.gov/ess/docs/pr_conferences/2 010/choi_pnnl.pdf

[4] Element energy, 2012. Cost and performance of the EV batteries. Final report for the committee on climate change. [WWW] Retrieved 20.10.2014 from

http://www.element-energy.co.uk/wordpress/wpcontent/uploads/2012/04/CCC-battery-cost Element-Energy-report_March2012_Public.pdf

[5] Pillot C. Avicenne - Battery Market Development for Consumer Electronics, Automotive, and Industrial: Materials, Requirements and Trends. Presentation slides AABC 2014 February 3-7 Atlanta, Georgia, USA. Pages 36.

[6] Zaghib, K. Mauger, A. Groult H. Goodenough J. Julien C. Advanced Electrodes for High Power Li-ion Batteries. 2013 MDPI - Open Access Publishing. ISSN 1996-1944

[7] Toshiba LTO datasheet [WWW] Retrieved 13.10.2014 from https://www.toshiba.com/tic/datafiles/SCiBBroch ure2014Final.pdf

[8] Altairnano LTO datasheet [WWW] Retrieved 13.7.2014 from http://www.altairnano.com/wpcontent/uploads/2011/10/60Ah-DataSheet.pdf

[9] Erkkilä K, Nylund N-O, Pellikka A-P, Kallio M, Kallonen S., Ojamo S., Ruotsalainen S., Pietikäinen O., Lajunen A., eBUS -Electric bus test platform in Finland. EVS27 Barcelona, Spain, November 17-20, 2013

[10] Measurement data provided by Ari Pekka Pellikka (VTT) by e-mail 20.6.2014.

[11] RekkEVidde, Assessing Range and Performance of Electric Vehicles in Nordic Driving Conditions [WWW] Retrieved 12.11.2014 from http://www.nordicenergy.org/wpcontent/uploads/2012/03/RekkEVidde.pdf

[12] Halmeaho, T. Electric City Buses - Mini-seminar report 2014 [WWW] Retrieved 11.7.2014 from https://noppa.aalto.fi/noppa/kurssi/as-

84.3210/luennot/AS-

84_3210_electric_city_buses.pdf

[13] Based on the interview with Riiko Kaurola Oy Tamware AB 15.11.2014

[14] NEMS: Electric Buses at Rotterdam F.G Rieck Future Mobility, Rotterdam University of Applied Science. [WWW] Retrieved 13.8.2014 from http://www.clean-fleets.eu/fileadmin/files/eBusz_Rotterdam_final_Ecomobiel-Bremen__Rieck_small_.pdf
[15] Reuters 27.10.2014: Goldman slashes 2015 oil price forecast as glut grows. [WWW] Retrieved 29.10.2014 from http://www.reuters.com/article/2014/10/27/oilforecast-goldman-idUSL4N0SM08A20141027

[16] Nasdaq OMX market prices for electricity forwards [WWW] Retrieved 13.10.2014 from http://www.nasdaqomx.com/commodities/market -prices

[17] Information provided by Kalle Keinonen TKL (Tampere City Transport) 16.6.2014.

[18] TOSA concept [WWW] Retrieved 13.9.2014 from http://www.tosa2013.com/\#/tosa201

[19] Altairnano product info. [WWW] Retrieved 13.9.2014 from www.altairnano.com/products/powerrack

[20] Swierczynski, M., Teodorescu R. Rodriguez, P. Lifetime investigations of a lithium iron phosphate (LFP) battery system connected to a wind turbine for forecast improvement and output power gradient reduction. International Stationary Battery Conference. "Battcon Archive Papers". Orlando: 2011, p. 20-1-20-8.

[21] Burke, A., Marshall, M., Hengbing, Z. 2012, Fast charging tests (up to $6 C$ ) of lithium titanate cells and modules: electrical and thermal response. University of California-Davis Institute of Transportation Studies. Research Report UCDITS-RR-12-07

\section{Authors:}

Olli Vilppo received his M.Sc degree in Industrial Engineering and Management from Tampere University of Technology in 2014. He is now working as a researcher at Tampere University of Technology. His main interests focus on business cases in EVs and electricity markets.

Joni Markkula received his M.Sc degree from Tampere University of Technology in 2013. He is now working as a researcher at Tampere University of Technology. His main interest focuses on business logic and business models in power system context. 